\title{
Drep í fingrum í kjölfar ísetningar slagæðaleggja - sjúkratilfelli
}

\author{
Atli Steinn Valgarðsson ${ }^{1}$ læknir \\ Sigurbergur Kárason ${ }^{2,3} \mid æ k n i r$ \\ Elín Laxdal ${ }^{1,3}$ ææknir \\ Kristín Huld Haraldsdóttir ${ }^{1,3} \mid æ k n i r$
}

1Skurðlækningadeild, ${ }^{2}$ svæfinga- og gjörgæsludeild Landspítala,
${ }^{3}$ æknadeild Háskóla Íslands.
Birt með leyfi sjúklings
Fyrirspurnum svarar Atli Steinn Valgarðsson, atlistei@landspitali.is

\section{Inngangur}

Slagæðaleggir eru notaðir hjá meirihluta sjúklinga sem leggjast inn á gjörgæsludeildir. Peir gefa mikilvægar rauntímaupplýsingar um blóðprýsting, vökvaástand og auðvelda til muna blóðsýnatökur úr slagæð. Leggjunum er oftast komið fyrir í sveifarslagæð (a. radialis), sjaldnar í ölnarslagæð (a. ulnaris) en aðrar æðar eru einnig notaðar. Mælt er með notkun slagæðaleggja hjá öllum sjúklingum með sýklasótt sem krefjast notkunar æðavirkra lyfja. ${ }^{1}$ Fylgikvillar eru fátíðir og oftast minniháttar og eru peir algengustu tímabundin blóðpurrð sem kemur fyrir í um fimmtungi tilfella, blóðgúll á stungustað eða sýndargúlpur (pseudoaneurysm) sem kemur sjaldnar fyrir. Alvarlegir fylgikvillar eins og sýklasótt eða varanlegur blóðpurrðarskaði eru mjög sjaldgæfir og koma fyrir í undir 0,15\% og 0,10\% tilfella. $^{2}$ Fáar rannsóknir eru til varðandi meðferð og meðferðarmöguleika sem í boði eru vegna pess hversu sjaldgæfur pessi fylgikvilli er. Hér er lýst tilfelli par sem sjúklingur hlaut drep í fingur eftir alvarleg veikindi og endurtekna ísetningu slagæðaleggja og peirri meðferð sem beitt var vegna pess.

\section{Tilfelli}

Tæplega 60 ára konu var vísað til Landspítala frá annarri heilbrigðisstofnun vegna bráđra kviðverkja og lostástands. Hún var með sögu um langvinna lungnateppu, reykingar og stoðkerfisverki sem meðhöndlaðir voru með bólgueyðandi lyfjum. Við frekari uppvinnslu kom í ljós rof á skeifugörn og pví var sjúklingurinn tekinn til bráðrar kviðsjáraðgerðar. Í aðgerðinni var sjúklingurinn með óstöðug lífsmörk og purfti verulegan stuðning æðavirkra lyfja. Skeifugarnarsárinu var lokað með einstaka saumum, lögð netja (omentum) yfir sárið og lagður keri í kviðarhol á aðgerðarsvæði. Eftir aðgerðina fluttist sjúklingurinn á gjörgæslu og purfti áfram mikinn æðavirkan stuðning með bæði noradrenalíni og vasopressíni. Premur dögum eftir aðgerðina fékk sjúklingur brátt hjartadrep með sleglahraðtakti, ST-hækkunum á hjartalínuriti og hækkun á hjartaensímum í blóði. Í ljósi lostástands og viðkvæms ástands í kviðarholi var í samráði við gjörgæslulækna, skurðlækna

\section{Á G R I P}

Inngangur: Notkun slagæðaleggja er algeng hjá gjörgæslusjúklingum vegna parfar fyrir rauntímaupplýsingar um blóðprýsting og vökvaástand sem notaðar eru til að stýra meðferð ásamt pví að vera notaðir til blóðsýnatöku. Alvarlegir fylgikvillar eru afar sjaldgæfir, en varanlegur blóðpurrðarskaði kemur fyrir hjá færri en 0,1\% sjúklinga. Tilfelli: Hér er sagt frá sjúklingi í sýklasóttarlosti á gjörgæsludeild sem gekkst undir aðgerơ vegna rofs á skeifugörn. Á annarri viku komu fram einkenni blóðpurrðar í öllum fingrum vinstri handar. Sjúklingurinn var fjölveikur, hafði purft háa skammta af æðavirkum lyfjum og purfti endurtekið að skipta um slagæðaleggi i mismunandi slagæðum, meðal annars í sveifarslagæð og ölnarslagæð vinstri handar. Beitt var blóðpynnandi meðferð sem sjúklingurinn poldi ekki vegna blæðinga frá meltingarvegi og pví dregið úr henni. Átta vikum síðar hafði afmarkast drep í öllum fingrum vinstri handar og í kjölfarið var framkvæmd aðgerð par sem hluti af fingrum II-V voru fjarlægðir en ekki purfti að gera aðgerð á pumli. Orsök drepsins er talin vera margpætt, meðal annars undirliggjandi ástands sjúklings, blóðsegi eđa blóðpurrð í kjölfar ísetningar slagæðaleggja.

Ályktun: Hér er lýst vel pekktum en mjög sjaldgæfum fylgikvilla slagæðaleggsísetningar og lögð fram tillaga að meðferðarferli sjúklinga með einkenni um blóðpurrðardrep í fingrum.

https://doi.org/10.17992/lbl.2018.12.208

og hjartalækna ákveðið að meðhöndla hjartadrepið með lágmarksblóðpynningu. Pví var hafin meðferð með blóðflöguhemli (asetýlsalicýlsýru), léttheparíni (enoxaparini) og beta-blokkum (metoprololi). Sama dag gekkst sjúklingur undir enduraðgerð vegna leka frá fyrri viðgerð, pá var lagður nýr keri og stoðneti komið fyrir með magaspeglunartæki til að pétta viðgerðina. Næstu daga voru lífsmörk óstöðug og purfti áfram umtalsverðan stuðning æðavirkra lyfja.

Æðaaðgangur var erfiður frá upphafi innlagnar og margsinnis purfti að skipta um bæði bláæða- og slagæðaleggi og purfti tímabundið að notast við sérstaka slagæðaleggi sem eru umtalsvert lengri (20G, 12cm) en hefðbundnir leggir (20G, 4,5cm). Settir voru slagæðaleggir ómstýrt í bæði ölnarslagæð og sveifarslagæð vinstri handar með stuttu millibili og einnig í sömu slagæðar hægri handar. Ekki liggur fyrir nákvæmlega hversu oft var skipt um slagæðaleggi eða staðsetning peirra en flestir peirra hættu að virka eftir einn til tvo sólarhringa. Erfitt getur verið að fullyrða um af hverju slagæðaleggir hætta að virka. аð getur verið vegna segamyndunar í peim, sérstaklega ef ekki er stöðugt sírennsli í gegnum pá eða ef ekki er skolað vel í gegnum pá eftir töku blóðsýna. Einnig getur komið brot í legginn sem kemur í veg fyrir að hann virki sem skyldi. 

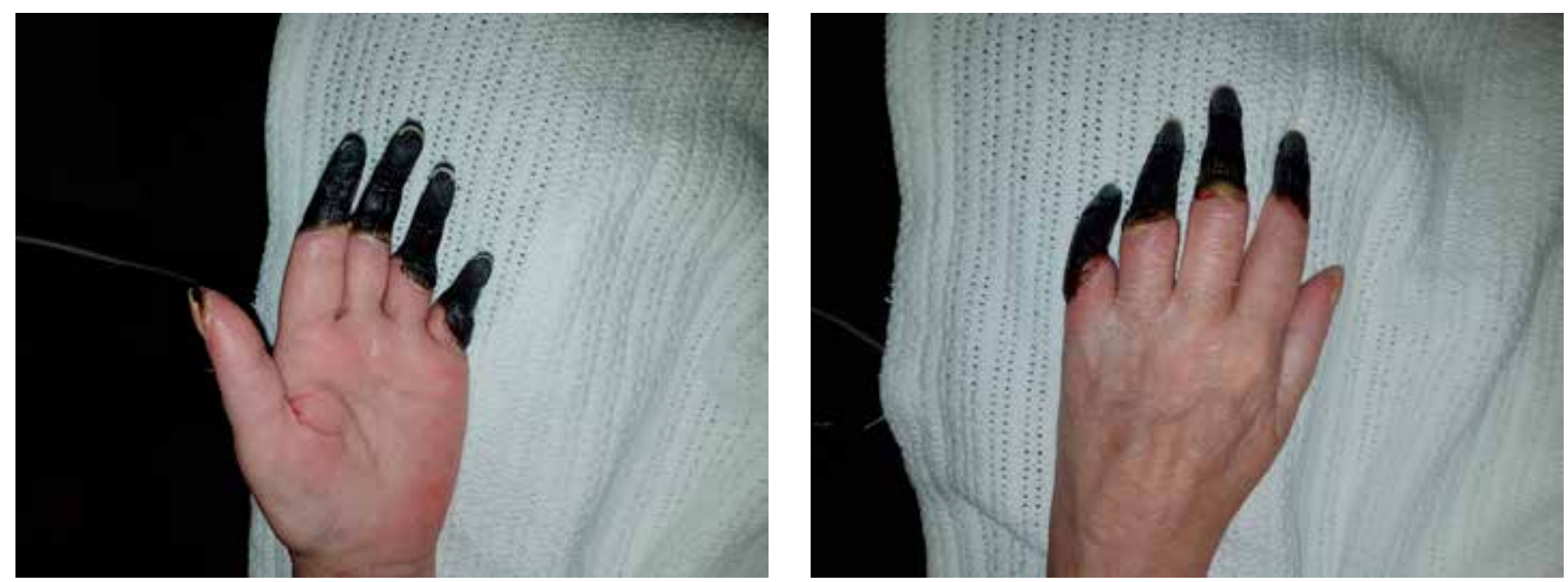

Mynd 1. Drep í fingrum vinstri handar. Myndin er tekin tæpum 8 vikum eftir að einkenna varð fyrst vart.

Í annarri viku eftir innlögn varð vart við skert blóðflæði í fingrum vinstri handar, höndin varð kaldari og greinilegur blámi á fingrum. Pví var slagæðaleggur úr ölnarslagæð sömu handar fjarlægður og einnig var minniháttar æðavirkum stuðningi, sem pá var til staðar, hætt.

Við skoðun nokkrum klukkustundum síðar voru fingur bláir og fölir og merki um drep yst í fingrum II-V. Skoðun með doppler sýndi góðan slátt yfir bæði ölnarslagæð og sveifarslagæð en ekki heyranlegan slátt yfir lófabogaslagæð (Arcus palmaris). Pví var talið líklegast að blóðtappi hefði borist í lófabogaslagæð og valdið blóðpurrð í fingrum. Vegna hættu á fylgikvillum hjá fjölveikum sjúklingi sem nýlega hafði gengist undir skurðaðgerð og í kjölfarið fengið blóðpurrðardrep í hjarta, pótti ekki ráðlegt að beita blóðsegaleysandi meðferð og par sem um smáar æðar var að ræða var ekki talið unnt að gera æðapræðingu eða skurðinngrip. Pví var hafin blóðpynningarmeðferð og pannig reynt að takmarka blóðpurrðarskaðann. Skammturinn af léttheparíni var aukinn og blóðflöguhemli haldið áfram í óbreyttum skömmtum. Á fyrsta degi eftir pessa lyfjabreytingu fór blóðrauði verulega lækkandi í

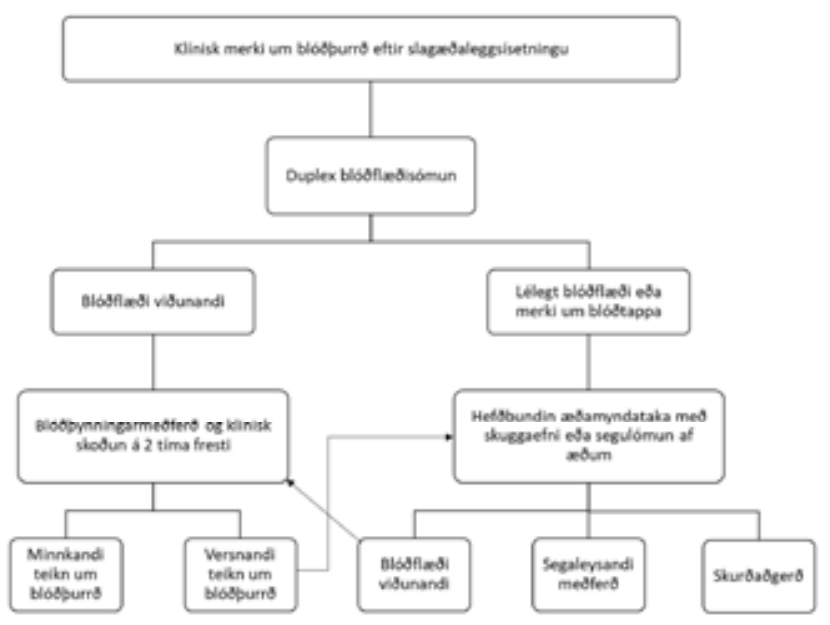

Mynd 2. Tillaga að uppvinnslu og meðferð pegar vart verður við blóðflæðiskerðingu eftir ísetningu slagæðaleggs. Myndin er unnin upp úr texta úr grein Türker og félaga frá $2014 .^{7}$ blóðprufum og blóð var greinanlegt í magaslöngu. Pví var dregið úr blóðpynningarmeðferð að nýju. Blæðing hélt áfram og kom blóð um kera í kviðarholi og purfti sjúklingur á blóðgjöf að halda. Í magaspeglun sást talsverð blóðstorka við skeifugarnarsárið og pví var ákveðið að draga enn frekar úr blóðpynningarmeðferð.

Á næstu vikum fór líkamlegt ástand sjúklingsins hægt batnandi en eftir stóð vitræn skerðing og var hún greind með Wernicke-Korsakoff heilkenni prátt fyrir ríkulega píamíngjöf. Drepið í fingrum afmarkaðist og var drep á öllum fingrum vinstri handar, minnst á pumli (mynd 1). Premur mánuðum eftir að einkenna varð fyrst vart var framkvæmd aðgerð par sem fjarlægð voru svæði með drepi á fingrum II-V en pumalfingur gréri án skurðaðgerðar. Sjúklingurinn útskrifaðist á nærliggjandi sjúkrahús en var endurinnlagður tveimur vikum síðar vegna sýklasóttarlosts sem rekja mátti til sýkingar út frá miðbláæðarlegg. Sjúklingurinn hefur síðan pá verið á batavegi og hefur náð góðum líkamlegum bata en eftir stendur pó vitræn skerðing.

\section{Umræða}

Hér er lýst tilfelli par sem pekktur en mjög sjaldgæfur fylgikvilli ísetningar slagæðaleggja átti sér stað. Lítið hefur verið birt pegar kemur að umræddum fylgikvilla og meðferð byggir oftast á reynslu fremur en stórum vönduðum rannsóknum. Sýnt hefur verið fram á með allmörgum rannsóknum að almennt er öruggt að fá æðaaðgang í ölnarslagæð pegar sveifarslagæð er stífluð en pessar rannsóknir hafa oftast verið á sjúklingum sem gangast undir kransæðapræðingu., ${ }^{3,4}$ Í flestum skráðum tilfellum par sem sjúklingar hafa fengið blóðpurrðardrep í tengslum við slagæðaleggi er um að ræða fjölveika gjörgæslusjúklinga í lostástandi og er dánartíðni há.,5-8 Áhættupættir fyrir blóðpurrð eftir slagæðaleggsísetningu eru óljósir. Margar tilraunir við uppsetningu og kvenkyn eru peir áhættupættir sem flestum rannsóknum ber saman um og er kynbundni munurinn talinn skýrast af pví að slagæðar kvenna eru almennt grennri en karla., ${ }^{2,8}, 9$

Par sem slagæðaleggir einir og sér eru sjaldnast nægjanleg ástæða varanlegrar blóðpurrðar í fingrum ${ }^{3,4}$ má álykta að orsökin fyrir drepinu í pessu tilfelli sé fjölpætt. Ætla má að orsökin í pessu tilfelli sé samblanda af alvarlegu lostástandi, stórum skömmtum 
æðavirkra lyfja, áhættupáttum hjarta- og æðasjúkdóma og endurtekinni ísetningu slagæðaleggja í bæði ölnar- og sveifarslagæð sömu handar, og samrýmist sú ályktun öðrum fræðigreinum sem ritaðar hafa verið um svipuð tilfelli. $5,7,8$

Meinalífeðlisfræðilegar ástæður blóðpurrðardreps sem pessa geta verið slagæðakrampi, mikill samdráttur í slagæðum vegna æðavirkra lyfja, lágur blóðprýstingur, útæðasjúkdómur í slagæðum, blóðtappi, segarek eða samverkan margra pessara pátta.

Meðferð sem helst hefur verið beitt í pessum tilfellum eru æðavíkkandi lyf gefin í bláæð eða slagæð, jafnvel borin á húð ef um krampa í slagæð er að ræða. Ef um blóðtappa er að ræða hafa verið notuð blóðpynningarlyf, segaleysandi lyf og einnig hafa blóðtappar verið fjarlægðir með skurðaðgerð eða æðapræðingu pegar pað er hægt. Pessar aðferðir hafa gefið misjafna raun og fá flestir sjúklingar með alvarlega blóðpurrð eftir ísetningu slagæðaleggja einhvern varanlegan vefjaskaða. ${ }^{8}$ Í grein frá árinu 2014 er gerð tillaga að pví hvernig bregðast mætti við einkennum um blóðpurrð í fingrum eftir slagæðaleggi (mynd 2). ${ }^{7}$ Par er mælt með að gera nákvæma skoðun og bendi hún til blóðpurrðar eigi að gera tvípátta-litaómun (duplex colored ultrasound) frekar en doppler-mælingu eina og sér par sem nokkrum tilfellum hefur verið lýst um eðlilega doppler-skoðun prátt fyrir verulega skert blóðflæði í slagæð. Ef merki eru um skert blóðflæði er mælt með að hefja blóð- pynningarmeðferð (mynd 2). Ef blóðflæði er áfram skert er mælt með æðamyndatöku og segaleysandi meðferð eða bráðaaðgerð ef um staðfesta lokun vegna blóðtappa í stærri slagæðum er að ræða, allt eftir umfangi blóðpurrðar og ástandi sjúklings. ${ }^{710}$ Staðbundin segaleysandi meðferð hefur reynst ágætlega í erfiðum tilfellum og árið 2003 var pví lýst hvernig gekk að opna æðar í fjórum sjúklingum af 7 með einkenni blóðpurrðar eftir slagæðaleggsísetningu. ${ }^{10}$ Í tilfellinu sem hér er lýst var sjúklingi ekki treyst í frekari æðamyndgreiningu eða blóðsegaleysandi meðferð vegna undirliggjandi sjúkdómsástands (nýleg skurðaðgerð á kviðarholi, blæðing frá kviðarholi og hjartadrep). Skurðaðgerð kom ekki til greina par sem um smáar æðar fjarlægt (distalt) við úlnlið var að ræða. Pví var ákveðið að beita blóðpynningarmeðferð sem sjúklingur poldi ekki og pví ákveðið að beita hægmeðferð (conservative treatment).

\section{Lokaorð}

Blóðpurrðardrep er mjög sjaldgæfur en alvarlegur fylgikvilli slagæðaleggsísetningar. Hann kemur helst fyrir í fjölveikum sjúklingum með marga áhættupætti. Mikilvægt er að allir sem koma að meðferð sjúklinga með slagæðaleggi pekki áhættupætti og einkenni skerts blóðflæðis og bregðist við pví eins fljótt og auðið er.

\section{Heimildir}

1. Rhodes A, Evans LE, Alhazzani W, Levy MM, Antonelli M, Ferrer R, et al. Surviving Sepsis Campaign: International Guidelines for Management of Sepsis and Septic Shock: 2016. Intensive Care Med 2017; 43: 304-77.

2. Scheer B, Perel A, Pfeiffer UJ. Clinical review: complications and risk factors of peripheral arterial catheters used for haemodynamic monitoring in anaesthesia and intensive care medicine. Crit Care 2002; 6: 199-204.

3. Hsueh S-K, Cheng C-I, Fang H-Y, Omran MM, Liu W-H, Chung $\mathrm{W}-\mathrm{J}$, et al. Feasibility and Safety of Transulnar Catheterization in Ipsilateral Radial Artery Occlusion. Int Heart J 2017; 58: 313-9.
4. Koutouzis M, Ziakas A, Didagelos M, Maniotis C, Kyriakides Z. Ipsilateral radial and ulnar artery cannulation during the same coronary catheterization procedure. Hippokratia 2016; 20: 249-51.

5. Lee KL, Miller JG, Laitung G. Hand ischaemia following radial artery cannulation. J Hand Surg Am 1995; 20: 493-5.

6. Garg K, Howell BW, Saltzberg SS, Berland TL, Mussa FF, Maldonado TS, et al. Open surgical management of complications from indwelling radial artery catheters. J Vasc Surg 2013; 58: 1325-30.
7. Türker T, Capdarest-Arest N. Acute hand ischemia after radial artery cannulation resulting in amputation. Chir Main 2014; 33: 299-302.

8. Valentine RJ, Modrall JG, Clagett GP. Hand ischemia after radial artery cannulation. J Am Coll Surg 2005; 201: 18-22.

9. Slogoff $\mathrm{S}$, Keats AS, Arlund C. On the safety of radial artery cannulation. Anesthesiology 1983; 59: 42-7.

10. Geschwind J-FH, Dagli MS, Lambert DL, Kobeiter H. Thrombolytic therapy in the setting of arterial lineinduced ischemia. J Endovasc Ther 2003; 10: 590-4.

\section{Finger necrosis following arterial cannulation - a case report}

\section{Atli Steinn Valgarðsson ${ }^{1}$ \\ Sigurbergur Kárason ${ }^{2,3}$ \\ Elín Laxdal ${ }^{1,3}$ \\ Kristín Huld Haraldsdóttir ${ }^{1,3,4}$}

Arterial cannulation is a common procedure in critically ill patients, as it facilitates continuous monitoring of blood pressure, titration of inotropes, vasopressors and fluids and is also used for blood sampling. Serious complications from arterial lines are very rare, permanent ischemic damage occurs in less than $0,1 \%$ of patients. We report the case of a 60 -year-old woman in septic shock caused by a perforated duodenal ulcer which was treated with emergent laparoscopic repair. She required high doses of vasopressors and received several arterial lines, including lines in both the ulnar and the radial arteries of the left arm. After two weeks in the intensive care unit she developed ischemia in all fingers of her left hand. She received anticoagulative therapy which was complicated by serious gastrointestinal bleeding and the therapy had to be discontinued. Eight weeks later she had demarcated necrosis in all fingers of her left hand and underwent partial amputation of fingers II-V, the thumb recovered without surgery. The cause of the necrosis was believed to be arterial embolism or ischemia secondary to arterial cannulations in combination with her underlying critical septic condition. 